Full Length Article

\title{
An Integrated Approach using Organic Amendments under a Range of Tillage Practices to Improve Wheat Productivity in a Cereal Based Cropping System
}

\author{
Ahmad Khan ${ }^{1 *}$, Mohammad Tariq Jan', Mohammad Afzal' ${ }^{1}$, Ihsan Muhammad ${ }^{2}$, Amanullah Jan ${ }^{1}$ and Zahir Shah ${ }^{2}$ \\ ${ }^{1}$ Department of Agronomy, The University of Agriculture, Peshawar, Pakistan \\ ${ }^{2}$ Department of Soil and Environmental Sciences, The University of Agriculture, Peshawar, Pakistan \\ *For Correspondence: ahmad0936@yahoo.com; khanahmad@aup.edu.pk
}

\begin{abstract}
Field studies were conducted over two years with the objectives to improve soil fertility and minimize the use of commercial fertilizer. It was comprised of three tillage practices included minimum (MT), conventional (CT) and deep (DT) and twelve nitrogen sources treatments including farm yard manure (FYM) $\left(10\right.$ or 20 tons ha $\left.{ }^{-1}\right)$, soybean residue (SR) (10 tons ha $\left.{ }^{-1}\right)$ in sole and/or in conjugation with half of inorganic nitrogen (UN) as urea (60 or $120 \mathrm{~kg} \mathrm{ha}^{-1}$ ), a control and sole full doses of inorganic N. Low soil fertility and yield was observed for deep tillage than minimum or conventional tillage. Minimum tillage improved soil fertility in term of mineral $\mathrm{N}$ as well crop productivity and uptake of $\mathrm{N}$ (11\%) compared to DT. FYM (20 tones $\left.\mathrm{ha}^{-1}\right)$ and UN (60 $\left.\mathrm{kg} \mathrm{ha}^{-1}\right)$ application improved soil fertility, crop productivity, and grain protein. Mixed application of FYM and urea increased total $\mathrm{N}$ uptake by plants and yield efficiency in term of harvest index was better for SR+UN treatment. Value cost ratio was higher for sole FYM, whereas relative increase in income was higher for FYM+UN. Thus using a mixture of FYM and UN under minimum tillage might be an optimum agronomic practice for improved productivity, soil fertility and economical disposition of waste material. Further studies are suggested to quantify the form of $\mathrm{N}$ uptake by plants for better and sustainable $N$ management practices in cereal base (wheat-maize) cropping system. (C) 2015 Friends Science Publishers
\end{abstract}

Keywords: Soybean residue; Farmyard manure; Soil N; Plant N uptake; Ploughing; Wheat

\section{Introduction}

Wheat (Triticum aestivum L.) yield and quality is influenced by the previous crop but largely depends on current year management practices (Wiatrak et al., 2006). Increase in soil fertility will boost production per unit area and plant growth. Higher application of nitrogenous fertilizer leads to water pollution (Semenov et al., 2007), therefore its application must be minimized, but not at the cost of minimizing crop productivity.

Minimum tillage (MT) can save more precipitation for crop production (Habtegebrial et al., 2007) and preserves soil biota and improves arable land in temperate region (Nakamoto et al., 2006). It reduce soil bulk density (Gangwar et al., 2006), N leaching (Sainju et al., 2006), pH and $\mathrm{CO}_{2}$ emission (Wang and Dalal, 2006). Improvement in soil organic C (Dolan et al., 2006), N enrichment (Habtegebrial et al., 2007), and slow release of nutrient upon gradual organic matter decomposition have all been observed for MT. Similarly, both deep and conventional tillage have been shown to improve soil porosity and aeration (Díaz-Zorita, 2000), conserved more soil moisture and nutrients for plants and microbes, provided oxygen for soil microflora (Patil and Sheelavantar, 2006), released more nutrients from soil microflora pool for crops, and thus ultimately increased crop yield (Díaz-Zorita, 2000).

Using off-farm organic material (David et al., 2005), combine use of commercial fertilizer and organic material (Ouédraogo et al., 2006) are considered to improve the crop productivity both in arid and semi-arid climates. These organic sources of $\mathrm{N}$ provides vital resources for improving soil fertility and thus crop productivity (Ortega et al., 2002) and organic matter (Blair et al., 2006a; Rasool et al., 2007), and is an alternative way of adding fertilizer to improve soil fertility and crop production (Wong et al., 1999).

Mineralization of organic residue increases available moisture (Kravchenko and Thelen, 2007), soil porosity, water holding capacity and infiltration rate (Gangwar et al., 2006), total and labile C (Blair et al., 2006a, b). It minimizes bulk density (Wong et al., 1999; Kravchenko and Thelen, 2007), decrease soil temperature (Kravchenko and Thelen, 2007), and results in increased essential plant nutrients (Kravchenko and Thelen, 2007). In addition to strengthening soil physiochemical properties, improvement

To cite this paper: Khan, A., M.T. Jan, M. Afzal, I. Muhammad, A. Jan and Z. Shah, 2015. An integrated approach using organic amendments under a range of tillage practices to improve wheat productivity in a cereal based cropping system. Int. J. Agric. Biol., 17: 467-474 
in yield of wheat, and physiological efficiency of $\mathrm{N}$ (Yadvinder-Singh et al., 2004) have been observed. Advantages of crop residue management systems over artificial $\mathrm{N}$ application include fuel and labour savings, lower machinery investments, and long-term benefits to soil structure and fertility.

The use of heavy machinery to prepare seed beds and continuous use of chemical fertilizer for improving crop productivity, led to consideration of alternative methods of crop production. Keeping the importance and constraints of tillage and $\mathrm{N}$ sources in view, the devising of a sound strategy to improve soil fertility and sustain crop productivity is needed. Thus, an appropriate cultural practice was designed with the objectives to test the influence of $\mathrm{N}$ and its source under different tillage practices for improved wheat productivity, growth, $\mathrm{N}$ uptake and soil nitrogen.

\section{Materials and Methods}

\section{Experimental Site}

The effect of different sources of organic and inorganic $\mathrm{N}$ added to soil under different tillage practices, were assessed in 2-year (2005-2007) field experiments at The University of Agriculture, Peshawar Pakistan, (71 ${ }^{\circ}, 35^{\prime} \mathrm{E}$ and $35^{\circ}, 41^{\prime}$ N). Spring wheat (cv. Saleem-2000) was used as test crop in wheat-maize-wheat cropping system. The soil of the experimental farm was well-drained and fine textured silt clay loam. The experimental site had semi-arid subtropical continental climate with a mean annual rainfall of about 360 $\mathrm{mm}$. The soil is deficient in total $\mathrm{N}\left(0.45 \mathrm{~g} \mathrm{~kg}^{-1}\right.$ soil $)$ and AB-DTPA extractable $\mathrm{P}$ (3.45 mg kg-1 soil), but has adequate AB-DTPA K (105 mg kg-1 soil) with a $\mathrm{pH}$ of 8.2 and organic matter content of $0.73 \%$. Rainfall data were collected in this site and are summarized in Fig. 1a, and compared with past 25 years data. In addition to rainfall, the crop water requirement was met by supplying water with flood irrigation when required.

\section{Materials and Treatments}

Seed were obtained from Agricultural Research Farm, the University of Agriculture, Peshawar, Pakistan. Three tillage practices i.e., deep (DT), conventional (CT) and minimum (MT) and 12 nitrogen management treatments were used. The nitrogen treatments included were: two UN levels (60 and $120 \mathrm{~kg} \mathrm{ha}^{-1}$ ), two farmyard manure (FYM) levels at the rate of 10 and $20 \mathrm{t} \mathrm{ha}^{-1}$ and level of soybean residue (SR) $\left(10 \mathrm{t} \mathrm{ha}^{-1}\right)$. The FYM and SR were used alone as well as supplemented with half of UN. A control plot without any fertilizer or residue was also included in each replication.

Deep tillage were carried out by chisel plough to till the soil down to $45 \mathrm{~cm}$ followed by common cultivator, whereas for CT only the common cultivator was used for 30 $\mathrm{cm}$ deep tilling the soil. In both cases the soil was ploughed two times across the field and twice times up and down it. In case of MT, the rotavator was used to bury the applied organic sources of $\mathrm{N}$ to the depth of 4-6 cm. After tillage, planking was done to break the clods, and smooth the field. Farm yard manure and SR were obtained from the Dairy Farm and Agricultural Research farm, of The Univesity of Agriculture, Peshawar, respectively. The FYM was well decomposed, whereas the soybean crop was harvested previous year. The physico-chemical composition of FYM and SR is shown in Table 1. Farmyard manure and soybean residue was incorporated in the soil 45 days prior to sowing in both seasons. Urea was applied in splits, half at sowing and remaining half just after first irrigation (after 27 days). Two weeks before manure or residue application, the field was irrigated uniformly by flood irrigation. Field history shows that before growing the first wheat crop in 2005, soybean was cultivated and was fertilized with single super phosphate at the rate of $80 \mathrm{~kg} \mathrm{P} \mathrm{ha}^{-1}$ at sowing.

Planting was done on $29^{\text {th }}$ October, 2005 for first wheat crop, on $16^{\text {th }}$ October, 2006 for second wheat crop. In all cases a tractor mounted planter equipped with row cleaner wheels was used. Phosphorus $\left(\mathrm{P}_{2} \mathrm{O}_{5}\right)$ and potash $\left(\mathrm{K}_{2} \mathrm{O}\right)$ were applied using $60 \mathrm{~kg} \mathrm{ha}^{-1}$ each as single super phosphate and sulphate of potash, respectively as basal dose. Weeds were controlled mechanically and with chemical herbicides using Affinity $400 \mathrm{DF}$ (a.i. $400 \mathrm{~g} \mathrm{~kg}^{-1}$ Carfentrazone-Ethyl). All agronomic and cultural practices including irrigation, weeding and hoeing etc were carried out uniformly for all the treatments in each replication.

\section{Experimental Design}

The experiment was trialled in split-plot design with three replications in each year. Nitrogen management treatments were arranged in subplots and tillage practices in the main plots. Subplot of $3 \mathrm{~m} \times 5 \mathrm{~m}$ having 10 rows $30 \mathrm{~cm}$ apart with 5 meter length, and a distance of $50 \mathrm{~cm}$ between two subplots, and main plots size of $21.5 \mathrm{~m} \mathrm{x} 10 \mathrm{~m}$ with a distance of $1 \mathrm{~m}$ between the main plots and replication were maintained in the experimental field.

\section{Observation and Measurements}

Three soil samples were taken from different position in each subplot at random from $15 \mathrm{~cm}$ depth and were mixed together for the soil mineral $\mathrm{N}$ determination. Soil sampling was done before and after growing each crop in all seasons (Keeney and Nelson, 1982). Number of spikes was recorded per unit area $\left(\mathrm{m}^{2}\right)$. Number of grains per spike was recorded by counting grains in randomly selected five spikes in each subplot and was averaged accordingly. Thousand grain weight was recorded on sensitive electronic balance after counting thousand grains with the help of seed counter for each subplot. Grain yield was recorded from each subplot after threshing separately and was expressed in $\mathrm{kg} \mathrm{ha}^{-1}$. Harvest index was calculated as the percent ratio of economic to biological yield. 
Nitrogen content in mature wheat grains $(12.7 \pm 0.2 \%$ moisture content) from harvested materials were also analyzed (Westerman, 1990) to determine grain protein content (AOAC, 1970). Total $\mathrm{N}$ uptake (i.e., the sum of $\mathrm{N}$ uptake by grains as well as straw calculated as the product of $\mathrm{N}$ content and respective plant components biomass) was worked to identify the potential usefulness of the treatments. The profitability of the organic and inorganic $\mathrm{N}$ under different tillage practices were carried out by the procedure of Boehlje and Eidman (1984). This method involves the project cost of production, gross revenue, and net return for a specified management alternative.

\section{Statistical Analysis}

Analysis of variance (ANOVA) was used to detect the significance of treatment effects on the different variables measured. In case of significant differences, least significance test, and standard error of means (Jan et al., 2009) were used to separate means. Special planned mean comparisons were also made to achieve the specific goals of research. The statistical software GenStat release 8.1 (GenStat, 2005) was used for analysis of all data.

\section{Results}

The mean values of temperature and rainfall during the crop season are shown in Fig. 1a. Mean air temperature was $8.87^{\circ} \mathrm{C}$ (January, 2007) to $31.98^{\circ} \mathrm{C}$ (June, 2007), whereas total rainfall per month varied between $0.00 \mathrm{~mm}$ (December, 2005 or June and July, 2007) and $80.00 \mathrm{~mm}$ (July, 2006). The climatic condition was in accordance with the past 25 years data (Fig. 1b), with the exception to rainfall during $2^{\text {nd }}$ year. Average rainfalls during grain filling (April onward) marked differently between 2 years. Thus, in order to avoid water stress during second year, we irrigated the plots, when required. As a consequence, the crop received an optimum water supply during grain filling in both years. The ABDTPA extractable $\mathrm{P}$ and $\mathrm{K}$ increased from 3.45 and 105 to 5.42 and $129 \mathrm{mg} \mathrm{kg}^{-1}$ soil, respectively during the course of experiments.

\section{Soil Mineral Nitrogen}

Mineral nitrogen increased with the passage of time linearly in all tillage practices (TP). This linear increment was significantly higher for minimum tillage (MT) than deep tillage (DT). Minimum tillage and conventional tillage (CT) had resulted in greater soil mineral $\mathrm{N}$ than DT in October, 2006 and May, 2007 (Table 2). The mineralization of farmyard manure (FYM) and/or soybean residue (SR) increased the mineral $\mathrm{N}$ with the lapse of time (Fig. 2). During May, 2006, mineral N (9.55 mg kg-1 soil) was higher in plots received 20 tons FYM ha ${ }^{-1}$ and $60 \mathrm{~kg}$ urea N ha (UN) compared to UN and/or control. These treatments performed in similar fashion through the mineralization period (Fig. 2). Control or UN amended plots had resulted in significantly lower mineral N. Plots receiving 20 tons FYM ha ${ }^{-1}$ combined with 30 or $60 \mathrm{~kg} \mathrm{UN} \mathrm{ha}^{-1}$ resulted in $110 \%$ more mineral $\mathrm{N}$ than control plot through entire period. Higher amount of FYM and SR mixed with UN plots produced more mineral $\mathrm{N}$ than either sole or lower levels of UN. Plots incorporated with FYM had more mineral $\mathrm{N}$ than SR applied plots (Fig. 2).

\section{Yield Components}

In 2005-2006, no differences for spike $\mathrm{m}^{-2}$ were observed for TP, however, in 2006-2007, spikes $\mathrm{m}^{-2}$ were higher in CT than DT (Table 3). Average over years, CT produced higher spike $\mathrm{m}^{-2}$ compared to DT. The comparison of nitrogen treatments showed that, $\mathrm{N}$ in the form of organic or inorganic whether alone or mixed increased spike $\mathrm{m}^{-2}$ over control (Table 3). Mixed application of FYM and UN produced more spike $\mathrm{m}^{-2}$ than sole application of either source. Sole UN application and FYM and/or SR showed no statistical variations in spikes $\mathrm{m}^{-2}$. However, spikes $\mathrm{m}^{-2}$ were higher in plots receiving 20 tons FYM ha ${ }^{-1}$ and $60 \mathrm{~kg} \mathrm{UN}$ $\mathrm{ha}^{-1}$ compared to other treatments. However, plots with mixed SR and UN resulted in more spike $\mathrm{m}^{-2}$ than sole SR.

Grains per spike were significantly higher fir MT or CT than DT (Table 3), with no statistical differences in MT and CT. Results indicated that both mineral and organic $\mathrm{N}$ increased grains per spike compared to control (Table 3). Mixed and higher level of FYM and UN resulted in higher grains per spike compared to other treatments, being highest when incorporated with 20 tons FYM ha ${ }^{-1}$ amended with 60 $\mathrm{kg} \mathrm{UN} \mathrm{ha}{ }^{-1}$. Sole SR incorporated plots produced less grain per spike than sole $120 \mathrm{~kg} \mathrm{UN} \mathrm{ha}^{-1}$ and/or mixed SR + UN. Minimum and conventionally ploughed plots have higher thousand grain weight (TGW) compared to deeply ploughed. However, the MT was not different in grain weight than recorded in CT (Table 3). Greater TGW was recorded from 20 tons FYM $+60 \mathrm{~kg} \mathrm{UN} \mathrm{ha}^{-1}$ compared to lower levels of $\mathrm{UN}$ or control (Table 3). In general no differences in TGW were observed for sole FYM or combined with UN soil incorporated. Interactive response of TP x NM revealed that in MT plots TGW was higher for FYM+UN compared to the SR+UN, whereas in DT plots the response was opposite (data not shown).

\section{Total N Uptake}

Total $\mathrm{N}$ uptake was higher $(11 \%)$ for MT than DT. Statistically, CT has greater total $\mathrm{N}$ uptake than DT. Maximum total $\mathrm{N}$ uptake (150.4 and $152.7 \mathrm{~kg} \mathrm{ha}^{-1}$ ) were recorded with incorporation of 20 tons FYM ha ${ }^{-1}$ combined with 30 or $60 \mathrm{~kg} \mathrm{UN} \mathrm{ha}^{-1}$, respectively, whereas minimum $\mathrm{N}$ uptake $\left(65.6 \mathrm{~kg} \mathrm{ha}^{-1}\right)$ was recorded in control plots. Plots receiving higher dose of $\mathrm{UN}$ have more total $\mathrm{N}$ uptake than lower dose of UN. Higher total $\mathrm{N}$ uptake was recorded from combined use of SR + UN compared to sole SR. All fertilized plots had more total $\mathrm{N}$ uptake than control plots. 


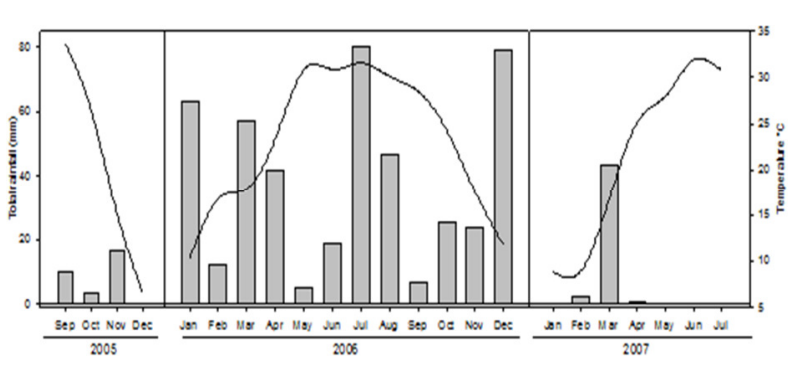

Fig. 1a: Total monthly rainfall $(\mathrm{mm})$ and average temperature during the experimental duration at experimental area

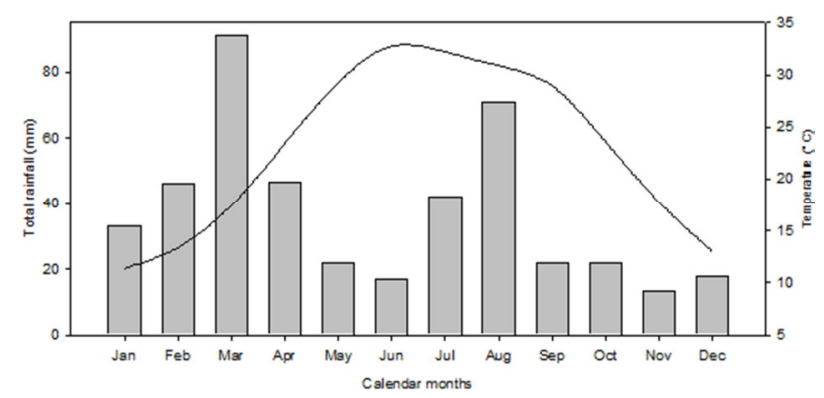

Fig. 1b: Total monthly rainfall $(\mathrm{mm})$ and average temperature average over past 25 years at experimental area

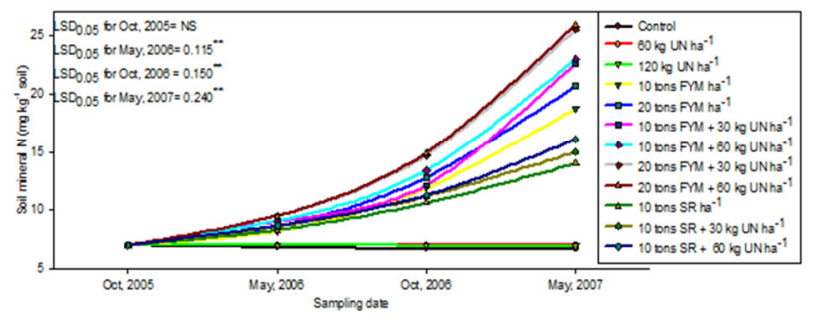

Fig. 2: Soil mineral $\mathrm{N} \mathrm{kg}^{-1}$ soil as affected by different sources and levels of $\mathrm{N}$ (FYM = farmyard manure, $\mathrm{UN}=$ Urea nitrogen, and SR = Soybean residue). LSD value is for comparison of different treatments at each sampling date

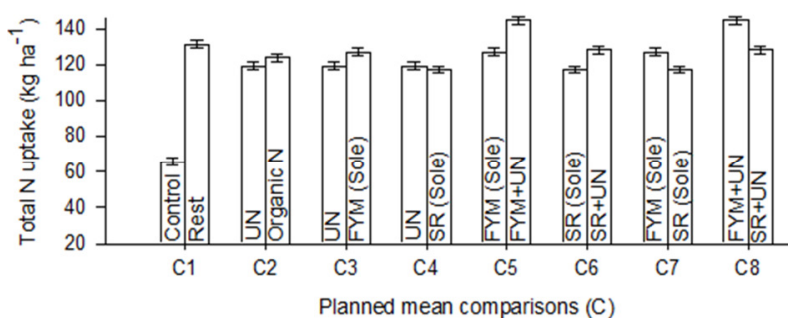

Fig. 3: Mean comparison for total $\mathrm{N}$ uptake $\left(\mathrm{kg} \mathrm{ha}^{-1}\right)$ as affected by $\mathrm{N}$ management treatments over tillage practices and years. Vertical bars are standard errors of means within each comparison
Table 1: Composition of farmyard manure and soybean residue used in the experiment

\begin{tabular}{lllll}
\hline Quality & & FYM & \multicolumn{2}{c}{ Soybean Residue } \\
parameters & $(\%)$ & $\left(\mathrm{kg} \mathrm{ton}^{-1}\right)$ & $(\%)$ & $\left(\mathrm{kg} \mathrm{ton}^{-1}\right)$ \\
\hline Total N & 1.11 & 11.1 & 3.12 & 31.2 \\
Mineral N & 0.12 & 1.12 & 0.15 & 1.5 \\
EC $\left(\mathrm{dS} \mathrm{m}^{-1}\right)$ & 4.92 & - & 5.21 & - \\
$\mathrm{pH}$ & 7.80 & - & 7.20 & - \\
Organic C & 16.2 & 162.0 & 18.7 & 187.0 \\
\hline
\end{tabular}

Table 2: Soil mineral nitrogen as affected by different tillage practices in wheat-maize cropping system

\begin{tabular}{|c|c|c|c|c|c|}
\hline \multirow[t]{3}{*}{ Treatments } & \multicolumn{5}{|c|}{ Sampling time (ST) } \\
\hline & Oct, 2005 & May, 2006 & Oct, 2006 & May, 2007 & Mean \\
\hline & \multicolumn{5}{|c|}{----------(mg mineral $\mathrm{N} \mathrm{kg}^{-1}$ soil)----------- } \\
\hline \multicolumn{6}{|l|}{ Tillage practices } \\
\hline Minimum & 7.03 & 8.41 & 11.28 & 17.08 & 10.95 \\
\hline Conventional & 7.05 & 8.40 & 11.22 & 16.95 & 10.90 \\
\hline Deep & 7.03 & 8.36 & 10.95 & 16.51 & 10.71 \\
\hline $\mathrm{LSD}_{0.05}$ & NS & $\mathrm{NS}$ & 0.230 & 0.368 & 0.939 \\
\hline
\end{tabular}

Generally, plots fertilized with UN were lower in total $\mathrm{N}$ uptake compared to FYM incorporated plots but was not different with SR application (Fig. 3).

\section{Yield and Yield Efficiency}

Grain yield recorded for MT was greater than DT both in individual as well over both years, but was not different from CT during 2005-2006 (Table 4). Conventional tillage showed least effects across the years. Grain yield during 2005-2006 ranged from $2507 \mathrm{~kg} \mathrm{ha}^{-1}$ (Control) to $4531 \mathrm{~kg}$ $\mathrm{ha}^{-1}$ (20 tons FYM ha ${ }^{-1}+60 \mathrm{~kg} \mathrm{UN} \mathrm{ha}^{-1}$ ), showing about $81 \%$ improvement in yield over control (Table 4). In following year (2006-2007), this increment over the control was about $84 \%$ for mixed application of 20 tons FYM $+60 \mathrm{~kg} \mathrm{UN} \mathrm{ha}^{-1}$. Based on mean data, the greater grain yield (4618 $\left.\mathrm{kg} \mathrm{ha}^{-1}\right)$ was achieved in plots incorporated with 20 tons FYM ha $^{-1}+$ $60 \mathrm{~kg} \mathrm{UN} \mathrm{ha}{ }^{-1}$ when compared with sole application of FYM, SR and control. Generally mixed and higher amount of FYM + UN application were better than lower and sole application of either source of N. Within those plots, which received SR, the mixed application was better than sole application. Interactive responses of TP $\mathrm{x}$ NM revealed that, FYM+UN was better for grain yield in all the three tillage practices, compared to sole FYM, however, the sole application of FYM had resulted in greater grain yield in CT compared to either MT or DT (data not shown).

Proportional increases in gain or biological yield (data not shown) due to tillage practices as well nitrogen treatments was similar and thus had resulted in nonsignificant difference for harvest index (HI). Harvest index ranged from 35.4 (control) to 37.2 (10 tons SR ha ${ }^{-1}+30 \mathrm{~kg}$ $\mathrm{UN} \mathrm{ha}{ }^{-1}$ ) based on average over years data. In MT plots, organic source of $\mathrm{N}$ had improved the $\mathrm{HI}$ compared to the $\mathrm{UN}$, whereas in DT plots UN promoted the HI compared to 
Nitrogen Management for Improved Soil Mineral N and Wheat Productivity / Int. J. Agric. Biol., Vol. 17, No. 3, 2015

Table 3: Spike $\mathrm{m}^{-2}$, grains per spike, thousand grain weight $(\mathrm{g})$ of wheat and total $\mathrm{N}$ uptake by wheat as affected by various $\mathrm{N}$ management treatments under a different tillage practices

\begin{tabular}{|c|c|c|c|c|}
\hline Treatments & No. of Spikes $\left(\mathrm{m}^{-2}\right)$ & Grains per spike & 1000 grain weight $(\mathrm{g})$ & Total $\mathrm{N}$ uptake $\left(\mathrm{kg} \mathrm{ha}^{-1}\right)$ \\
\hline \multicolumn{5}{|l|}{ Tillage practices $(\mathrm{T})$} \\
\hline Minimum & 251 & 48 & 40.20 & 131.6 \\
\hline Conventional & 255 & 48 & 40.26 & 126.4 \\
\hline Deep & 227 & 44 & 39.32 & 119.2 \\
\hline $\operatorname{LSD}_{0.05}$ & 12 & 2 & 0.47 & 3.6 \\
\hline \multicolumn{5}{|c|}{ Nitrogen management (NM) } \\
\hline Control & 215 & 41 & 38.61 & 65.6 \\
\hline UN-60 $\left(\mathrm{kg} \mathrm{ha}^{-1}\right)$ & 230 & 44 & 39.17 & 109.3 \\
\hline UN-120 (kg ha $\left.{ }^{-1}\right)$ & 250 & 48 & 40.49 & 129.0 \\
\hline FYM-10 $\left(\mathrm{Mg} \mathrm{ha}^{-1}\right)$ & 243 & 44 & 39.41 & 123.7 \\
\hline FYM-20 $\left(\mathrm{Mg} \mathrm{ha}^{-1}\right)$ & 247 & 47 & 39.80 & 130.3 \\
\hline FYM-10 + N-30 & 251 & 49 & 40.12 & 133.2 \\
\hline FYM-10 + N-60 & 258 & 50 & 40.32 & 141.5 \\
\hline FYM-20 + N-30 & 265 & 50 & 40.55 & 150.4 \\
\hline FYM-20 + N-60 & 267 & 51 & 40.77 & 152.7 \\
\hline SR-10 $\left(\mathrm{Mg} \mathrm{ha}^{-1}\right)$ & 225 & 44 & 39.50 & 117.2 \\
\hline SR-10 + N-30 & 239 & 45 & 40.05 & 123.1 \\
\hline SR-10 + N-60 & 244 & 48 & 40.36 & 133.2 \\
\hline $\mathrm{LSD}_{0.05}$ & 16 & 2 & 0.68 & 5.8 \\
\hline \multicolumn{5}{|l|}{ Interactions ( $\mathrm{p}$ value) } \\
\hline $\mathrm{Y} \times \mathrm{T}$ & 0.207 & 0.150 & 0.542 & 0.791 \\
\hline $\mathrm{Y} \times \mathrm{NM}$ & 0.960 & 0.471 & 0.999 & 0.435 \\
\hline $\mathrm{T} \times \mathrm{NM}$ & 0.836 & 0.923 & 0.000 & 0.512 \\
\hline $\mathrm{Y} \times \mathrm{T} \times \mathrm{NM}$ & 0.968 & 0.960 & 0.993 & 0.998 \\
\hline
\end{tabular}

$\mathrm{UN}=$ urea nitrogen, FYM= Farmyard manure, $\mathrm{SR}=$ Soybean residue, $\mathrm{Y}=$ year

Table 4: Grain yield and protein $(\%)$ of wheat as affected by various $\mathrm{N}$ management treatments under a different tillage practices

\begin{tabular}{|c|c|c|c|c|c|c|}
\hline \multirow[t]{2}{*}{ Treatments } & \multicolumn{3}{|c|}{ Grain yield $\left(\mathrm{kg} \mathrm{ha}^{-1}\right)$} & \multicolumn{3}{|c|}{ Grain protein content $(\%)$} \\
\hline & $2005-2006$ & 2006-2007 & Mean & $2005-2006$ & 2006-2007 & Mean \\
\hline \multicolumn{7}{|l|}{ Tillage practices $(\mathrm{T})$} \\
\hline Minimum & 3937 & 4212 & 4074 & 11.89 & 12.32 & 12.10 \\
\hline Conventional & 3929 & 4141 & 4035 & 11.73 & 12.45 & 12.09 \\
\hline Deep & 3695 & 3995 & 3845 & 11.71 & 12.29 & 12.00 \\
\hline $\mathrm{LSD}_{0.05}$ & 184.3 & 156.3 & 100 & & & \\
\hline \multicolumn{7}{|c|}{ Nitrogen management (NM) } \\
\hline Control & 2099 & 2153 & 2126 & 10.85 & 10.95 & 10.90 \\
\hline UN-60 (kg ha $\left.{ }^{-1}\right)$ & 3322 & 3533 & 3428 & 11.35 & 11.84 & 11.60 \\
\hline UN-120 (kg ha-1) & 3966 & 4281 & 4123 & 11.93 & 12.40 & 12.16 \\
\hline FYM-10 (Mg ha $\left.{ }^{-1}\right)$ & 3882 & 4127 & 4005 & 11.69 & 12.28 & 11.98 \\
\hline FYM-20 $\left(\mathrm{Mg} \mathrm{ha}^{-1}\right)$ & 3972 & 4223 & 4098 & 11.76 & 12.42 & 12.09 \\
\hline FYM-10 + N-30 & 4066 & 4344 & 4205 & 11.90 & 12.47 & 12.18 \\
\hline FYM-10 + N-60 & 4200 & 4496 & 4348 & 12.22 & 13.03 & 12.63 \\
\hline FYM-20 + N-30 & 4440 & 4760 & 4600 & 12.57 & 13.29 & 12.93 \\
\hline FYM-20 + N-60 & 4456 & 4780 & 4618 & 12.75 & 13.12 & 12.94 \\
\hline SR-10 (Mg ha $\left.{ }^{-1}\right)$ & 3784 & 4059 & 3921 & 11.19 & 11.91 & 11.55 \\
\hline SR-10 + N-30 & 3945 & 4225 & 4085 & 11.39 & 12.12 & 11.75 \\
\hline SR-10 + N-60 & 4110 & 4414 & 4262 & 11.71 & 12.39 & 12.05 \\
\hline $\mathrm{LSD}_{0.05}$ & 232 & 236 & 164 & 0.45 & 0.11 & 0.60 \\
\hline Mean of years & 3854 & 4116 & & 11.77 & 12.35 & \\
\hline \multicolumn{7}{|l|}{ Interactions ( $\mathrm{P}$ value) } \\
\hline $\mathrm{Y} \times \mathrm{T}$ & - & - & 0.600 & - & - & 0.493 \\
\hline $\mathrm{Y} \times \mathrm{NM}$ & - & - & 0.955 & - & - & 0.962 \\
\hline $\mathrm{T} \times \mathrm{NM}$ & 0.294 & 0.361 & 0.004 & 0.292 & 0.213 & 0.638 \\
\hline $\mathrm{Y} \times \mathrm{T} \times \mathrm{NM}$ & - & - & 1.000 & - & - & 1.000 \\
\hline
\end{tabular}

${ }^{\#}$ Percent of grand mean, $\mathrm{N}=$ urea nitrogen, FYM= Farmyard manure, $\mathrm{SR}=$ Soybean residue

Grain yield data presented at $14^{\text {th }}$ Australian Agronomy conference, September 2008 (Khan et al., 2008a)

organic source. More specifically, the UN had performed better for HI in DT plots when compared to sole FYM incorporations, whereas MT and CT performed similarly. However, SR had higher HI in MT plots than UN, but the response was opposite in DT plots.

\section{Grain Protein}

Grain protein (\%) was significantly affected by years and Nitrogen treatments but was not affected by tillage and all interactions (Table 4). Grain protein was higher in second 
Khan et al. / Int. J. Agric. Biol., Vol. 17, No. 3, 2015

Table 5: Economic consideration of production technology using different sources of nitrogen

\begin{tabular}{|c|c|c|c|c|c|c|c|c|c|c|}
\hline $\begin{array}{l}\text { Nitrogen } \\
\text { management }\end{array}$ & $\begin{array}{l}\text { Grain yield } \\
\left(\mathrm{kg} \mathrm{ha}^{-1}\right)\end{array}$ & $\begin{array}{l}\text { Straw yield } \\
\left(\mathrm{kg} \mathrm{ha}^{-1}\right)\end{array}$ & $\begin{array}{l}\text { Grain } \\
\text { Value (\$) }\end{array}$ & $\begin{array}{l}\text { Straw } \\
\text { Value }(\$)\end{array}$ & $\begin{array}{l}\text { Gross } \\
\text { income (\$) }\end{array}$ & $\begin{array}{l}\text { Gross income } \\
\text { over control (\$) }\end{array}$ & $\begin{array}{l}\text { Total } \\
\text { expenditure }(\$)\end{array}$ & $\begin{array}{l}\text { Net income over } \\
\text { control (\$) }\end{array}$ & $\begin{array}{l}\text { Value } \\
\text { cost ratio }\end{array}$ & $\begin{array}{l}\text { RII } \\
(\%)\end{array}$ \\
\hline Control & 2507 & 4621 & 780.7 & 200.9 & 981.6 & 0 & 0 & 0 & - & - \\
\hline $\mathrm{UN}-60\left(\mathrm{~kg} \mathrm{ha}^{-1}\right)$ & 3627 & 6758 & 1129.6 & 293.8 & 1423.4 & 441.8 & 40.5 & 401.0 & 9.9 & 40.9 \\
\hline $\mathrm{UN}-120\left(\mathrm{~kg} \mathrm{ha}^{-1}\right)$ & 4156 & 7376 & 1294.2 & 320.8 & 1615.0 & 633.4 & 81.3 & 552.1 & 6.8 & 56.2 \\
\hline FYM-10 (Mg ha $\left.{ }^{-1}\right)$ & 4004 & 7363 & 1247.0 & 320.1 & 1567.1 & 585.5 & 20.8 & 564.7 & 27.2 & 57.5 \\
\hline FYM-20 $\left(\mathrm{Mg} \mathrm{ha}^{-1}\right)$ & 4097 & 8233 & 1275.9 & 358.0 & 1633.8 & 652.2 & 41.5 & 610.6 & 14.7 & 62.2 \\
\hline FYM-10 + N-30 & 4210 & 7809 & 1311.0 & 339.6 & 1650.6 & 669.0 & 41.0 & 627.8 & 15.3 & 64 \\
\hline FYM-10 + N-60 & 4347 & 8088 & 1353.7 & 351.7 & 1705.4 & 723.8 & 61.3 & 662.3 & 10.8 & 67.5 \\
\hline FYM-20 + N-30 & 4599 & 8096 & 1432.2 & 352.0 & 1784.2 & 802.6 & 61.8 & 740.8 & 12 & 75.5 \\
\hline FYM-20 + N-60 & 4618 & 8498 & 1438.1 & 369.5 & 1807.6 & 826.0 & 82.1 & 743.9 & 9.1 & 75.8 \\
\hline SR-10 $\left(\mathrm{Mg} \mathrm{ha}^{-1}\right)$ & 3921 & 6930 & 1221.1 & 301.3 & 1522.4 & 540.7 & 103.8 & 436.9 & 4.2 & 44.5 \\
\hline SR-10+N-30 & 4085 & 7070 & 1272.1 & 307.4 & 1579.5 & 597.9 & 124.1 & 473.8 & 3.8 & 48.3 \\
\hline SR $-10+N-60$ & 4261 & 7612 & 1326.9 & 330.9 & 1658.0 & 676.2 & 144.4 & 531.8 & 3.7 & 54.2 \\
\hline
\end{tabular}

RII=Relative increase in income, UN= urea nitrogen, FYM= Farmyard manure, SR= Soybean residue

$\$=$ US Dollar (equivalency =PKRs. 103). Price are based on local market

year than the first year, suggesting more $\mathrm{N}$ uptake by plants and transformation to grain in the second year. In 2005-2006, grain protein varied form $10.8 \%$ (control) to $12.8 \%$ (20 tons FYM ha $\left.{ }^{-1}+60 \mathrm{~kg} \mathrm{UN} \mathrm{ha}^{-1}\right)$, whereas in the following year it was in the range of $11 \%$ (control) to $13.1 \%$ (20 tons FYM $\left.\mathrm{ha}^{-1}+60 \mathrm{~kg} \mathrm{UN} \mathrm{ha}^{-1}\right)$. Mean of both years were in the range of $10.9 \%$ (control) to $12.9 \%$ (20 tons FYM ha ${ }^{-1}$ reinforced with either 30 or $\left.60 \mathrm{~kg} \mathrm{UN} \mathrm{ha}^{-1}\right)$. Generally, mixed and higher dose of FYM + UN application resulted in quality grains having more protein compared to control, sole and lower levels of FYM and UN. In the same way, plots incorporate with $\mathrm{SR}$ and reinforced $\mathrm{N}$ have produced quality grains than sole SR received plots.

\section{Economic Consideration}

Economic analysis data regarding $\mathrm{N}$ source treatment are presented in Table 5. Generally, FYM whether mixed with $\mathrm{UN}$ or alone, showed higher value cost ratio (VCR) and relative increase in income (RII) compared to UN and/or SR. The highest VCR (27.2) was obtained for 10 tons FYM ha ${ }^{-1}$, with gross and net income over control of $\$ 585.5$ and $\$ 564.7$, respectively, suggesting the low price for FYM. However, its RII was lower (57.3\%) than other FYM treatments. Highest gross and net income over control of $\$ 505.2$ and $\$ 455.0$ were recorded for 20 tons FYM ha ${ }^{-1}$ mixed with $60 \mathrm{~kg} \mathrm{UN} \mathrm{ha}^{-1}$, with VCR of 10.2 but highest RII of $75.8 \%$. Due to more expenditure incurred on SR application it VCR were lower than all other treatments, but RII was in the range of 44.5$4.2 \%$. Beside monetary benefits, the FYM application mixed with $\mathrm{UN}$ improved soil mineral $\mathrm{N}$ and thus have positive effects on the environments and human health, energy conservation, soil quality and fertility.

\section{Discussion}

Mineral $\mathrm{N}$ measured in MT and CT was greater than DT during latter stages (following year), suggesting the more mineralization of organic residue (Papini et al., 2007), more microbial biomass in minimum tilled plots, or might be due to more efficiently utilization of $\mathrm{N}$ (Nakamoto et al., 2006). The demand and supply of $\mathrm{N}$ under MT would synchronized and thus resulted in less $\mathrm{N}$ losses by leaching (Sainju et al., 2006) unlike conventionally or deep tillage, where soil $\mathrm{N}$ and organic $\mathrm{C}$ was lower. Greater mineral $\mathrm{N}$ measured in $\mathrm{N}$ applied plots compared to control would be better explained either due to residual effect of $\mathrm{N}$ and/or mineralization of organic source of $\mathrm{N}$. Incorporated of mixed FYM + UN resulted in more mineral $\mathrm{N}$ than either sole application of UN or FYM. The greater mineralization potential would be the possible explanation for higher mineral N (Ortega et al., 2002), and the addition of small amount of $\mathrm{UN}$ further improved $\mathrm{N}$ mineralization of organic source (Kravchenko and Thelen, 2007), as initially, microbes need some energy in the farm of starter UN to initiate mineralization process (Blair et al., 2006a). The lower mineral $\mathrm{N}$ in $\mathrm{SR}$ would probably be due to immobilization of $\mathrm{N}$ due to wider $\mathrm{C} / \mathrm{N}$ ratio of the treatments. One of the problems associated with organic manuring is the handling of bulky organic materials, which would be probably managed by enrichment of manure with a small amount of inorganic $\mathrm{N}$.

Greater spike $\mathrm{m}^{-2}$, grains per spike and TGW were recorded in MT and CT compared to DT. Greater soil water content (Khan et al., 2008a), residual N (Sainju et al., 2006), and organic C (Dolan et al., 2006) in minimum tilled soil would be associated with better crop performance, and thus had increased yield components when compared to DT. Generally, mixed and higher dose of FYM+UN produced better yield components than control. The carry-over effects of organic and inorganic $\mathrm{N}$ from the previous crop and more mineral N (Kravchenko and Thelen, 2007), total N (Dolan et al., 2006), and/or other micro nutrients (Wong et al., 1999) might be the possible reasons for improved crop productivity in organic manured plots compared to control. The residue incorporation improve total $\mathrm{N}$ (Malhi et al., 2006), but in the present study the decomposition time for SR was slow, thus with little improvement in yield. The improved crop stand and phenology (Khan et al., 2008b) could be the other possible explanation for improved yield 
components. The lower $\mathrm{N}$ level in the soil resulted in decreased yield component might be due to less available $\mathrm{N}$ for the optimum plant growth.

Minimum tillage had higher total $\mathrm{N}$ uptake than tilled deeply. The higher accumulation of $\mathrm{N}$ with minimum tillage might be due to greater mineralization (Sainju et al., 2006) or better soil physical conditions owing to microbial activity (Nakamoto et al., 2006) or minimum leaching loss (Rasmussen, 1999) and consequently more $\mathrm{N}$ uptake by aerial parts (López-Bellido et al., 2003). Integrated application of FYM and higher levels of UN resulted in greater total $\mathrm{N}$ uptake compared to other treatments. The higher uptake of $\mathrm{N}$ might be associated with the mineralization-immobilization turnover (Sainju et al., 2006), which resulted in greater $\mathrm{N}$ loses though immobilization in lower $\mathrm{N}$ dose treatments. The other possible reason might be the greater mineralization of organic matter (Walters et al., 1992; Aulakh et al., 2000) in to available N, which might increased the $\mathrm{N}$ uptake in straw and grains. Increasing $\mathrm{N}$ rate increased the uptake of $\mathrm{N}$ (Fan et al., 2005) would be better correlated due to more available $\mathrm{N}$ due to $\mathrm{N}$ released from organic source (López-Bellido et al., 2003).

The higher yield in MT or CT would be associated with the individual crop performance in term of yield components (Table 3) or would be associated to the consequence of preserved soil biota (Nakamoto et al., 2006), more water retention (Khan et al., 2008a; Thomas et al., 2007), enhanced fertility (Papini et al., 2007), decreases soil compaction, increases nutrient availability (Sainju et al., 2006) and enhanced phenology (Khan et al., 2008b). Retention of plant residues near soil surface resulted in lower evapo-transpiration, higher content of soil water, lower soil temperature, more nutrients and organic matter, less soil $\mathrm{pH}$, and more stable soil aggregates (Rasmussen, 1999) and thus improved yield and yield efficiency. Organic amendments when coupled with fertiliser applications increased crop yields and soil organic matter and soil fertility (Blair et al., 2006b) and are one of the most common rehabilitation practices to improve soil physiochemical properties (Celik et al., 2004). Similarly (Sainju et al., 2006), reported that slow decomposition of organic matter, is a key factor for increasing soil fertility, and reducing soil erosion under reduced tillage. Harvest index was not affected by tillage practices, advocating the similar proportional increases in economical and biological yield. The protein content of grain was not affected by tillage practices, suggesting similar $\mathrm{N}$ uptake by plants (Dang et al., 2006) in deeply or low tilled plots, or would be due to the confound effects of nitrogen treatments. Our results corresponds with the findings of Habtegebrial et al. (2007), who reported no variation in grain $\mathrm{N}$ content of wheat followed by cotton (Wiatrak et al., 2006). Grain protein content was higher with incorporation of $\mathrm{N}$ than control. Generally, mixed application of FYM and UN was far better than either control, sole FYM and/or SR. Nitrogen fertilization improved photosynthetic capabilities of plants and hence protein and thereby grain quality. Our results is supported by the finding of (Barbottin et al., 2005), who were of the opinion that incorporation of $\mathrm{N}$ into the soil influence the $\mathrm{N}$ accumulation and increased grain protein. Greater mineralization in fertilized plots (Soon et al., 2001) would increase soil $\mathrm{N}$ and thus grain protein. Mineralization of $\mathrm{N}$ would be consistent with the greater microbial biomass, organic $\mathrm{N}$, mineralizable $\mathrm{N}$, and recycling of $\mathrm{N}$.

Since soils of the central plains of the North Western Pakistan were put under cultivation, which might have resulted in less productivity as a consequence of organic matter losses associated with an extensive tillage. Researchers showed that soil $\mathrm{C}$ and $\mathrm{N}$ levels decline with years of cultivation, and this inclination can be minimized by diverging to conservation practices like stubble mulch or reduced tillage. Conservation and supplementation of organic residue or manure strategies provides vital natural resources for conserving soil productivity (Ortega et al., 2002), and can be regarded as an alternative way of adding fertilizer to increase soil fertility and crop productivity (Wong et al., 1999). Thus, conversion to reduced tillage and manure supplementation to soil in addition to inorganic fertilizers have direct effects on financial status of the farmer in term of reducing implements cost and increased grain yield, profitability and soil conditions. Value cost ratio (VCR) was higher for 10 tons FYM ha ${ }^{-1}$ compared to other treatments, suggesting low price for FYM. The enrichment of FYM with urea has decreased its VCR, but increased gross and net income over control and also RII (relative increase in income). Most of the researcher used VCR for economic consideration, but in this particular situation, the VCR was not coinciding with grain yield and other benefits, thus RII (Yinbo et al., 1997) was calculated and treatment were evaluated for its economic return. In addition to economic benefits obtained from mixed application of FYM and urea, improved $\mathrm{N}$ is comparable for soil quality. Thus, mixed application of FYM and urea is the alternative way for improving soil quality as well as improving resource poor farmer's income.

\section{Conclusion}

Tillage influence was restricted to soil mineral $\mathrm{N}$ only during latter stages, yield and yield components being higher for either MT or CT than DT, but did not improve grain protein content. Higher $\mathrm{N}$ in the form of 20 tons FYM $\mathrm{ha}^{-1}$ and $60 \mathrm{~kg} \mathrm{UN} \mathrm{ha}{ }^{-1}$ had improved yield and yield components, $\mathrm{N}$ uptake and quality of grains. Relative increase in income was higher for higher levels of 20 tons FYM ha ${ }^{-1}$ and $60 \mathrm{~kg} \mathrm{UN} \mathrm{ha}^{-1}$ compared to lower levels or sole application of either.

\section{Acknowledgements}

The authors acknowledge HEC for financing this research through the Indigenous $\mathrm{Ph} \mathrm{D}$ Scholarship program. 


\section{References}

AOAC, 1970. Official Methods of Analysis of the Association of Official Analytical Chemists. In. Washington DC, USA

Aulakh, M.S., T.S. Khera, J.W. Doran, Kuldip-Singh and Bijay-Singh, 2000. Yields and nitrogen dynamics in a rice-wheat system using green manure and inorganic fertilizer. Soil Sci. Soc. Amer. J., 64: $1867-1876$

Barbottin, A., C. Lecomte, C. Bouchard and M.H. Jeuffroy, 2005. Nitrogen remobilization during grain filling in wheat. Crop Sci., 45: $1141-1150$

Blair, N., R.D. Faulkner, A.R. Till and P.R. Poulton, 2006b. Long-term management impacts on soil C, $\mathrm{N}$ and physical fertility: Part I: Broadbalk experiment. Soil Till. Res., 91: 30-38

Blair, N., R.D. Faulkner, A.R. Till, M. Korschens and E. Schulz, 2006a. Long-term management impacts on soil $\mathrm{C}, \mathrm{N}$ and physical fertility: Part II: Bad Lauchstadt static and extreme FYM experiments. Soil Till. Res., 91: 39-47

Boehlje, M.D. and V.R. Eidman, 1984. Farm Management. IJohn Wiley and Sons, New York, USA

Celik, I., I. Ortas and S. Kilic, 2004. Effects of compost, mycorrhiza, manure and fertilizer on some physical properties of a Chromoxerert soil. Soil Till. Res., 78: 59-67

Dang, T.H., G.X. Cai, S.L. Guo, M.D. Hao and L.K. Heng, 2006. Effect of nitrogen management on yield and water use efficiency of rainfed wheat and maize in northwest china. Pedosphere, 16: 495-504

David, C., M.H. Jeuffroy, F. Laurent, M. Mangin and J.M. Meynard, 2005. The assessment of Azodyn-Org model for managing nitrogen fertilization of organic winter wheat. Eur. J. Agron., 23: 225-242

Díaz-Zorita, M., 2000. Effect of deep-tillage and nitrogen fertilization interactions on dryland corn (Zea mays L.) productivity. Soil Till. Res., 54: 11-19

Dolan, M.S., C.E. Clapp, R.R. Allmaras, J.M. Baker and J.A.E. Molina, 2006. Soil organic carbon and nitrogen in a Minnesota soil as related to tillage, residue and nitrogen management. Soil Till. Res., 89: 221-231

Fan, M., R. Jiang, X. Liu, F. Zhang, S. Lu, X. Zeng and P. Christie, 2005. Interactions between non-flooded mulching cultivation and varying nitrogen inputs in rice-wheat rotations. Field Crops Res., 91: 307-318

Gangwar, K.S., K.K. Singh, S.K. Sharma and O.K. Tomar, 2006. Alternative tillage and crop residue management in wheat after rice in sandy loam soils of Indo-Gangetic plains. Soil Till. Res., 88: 242-252

GenStat, 2005. GenStat, $8^{\text {th }}$ edition. Release 8.1. VSN International, Oxford UK

Habtegebrial, K., B.R. Singh and M. Haile, 2007. Impact of tillage and nitrogen fertilization on yield, nitrogen use efficiency of tef (Eragrostis tef (Zucc.) Trotter) and soil properties. Soil Till. Res., 94: $55-63$

Jan, M.T., P. Shah, P.A. Hoolington, J.M. Khan and Q. Sohail, 2009. Agriculture Res.: Design and Analysis. Department of Agronomy, Khyber Pakhtunkhwa Agricultural University, Peshawar Pakistan

Keeney, D.R. and D.W. Nelson, 1982. Nitrogen-Inorganic Form. In Method of Soil Analysis, Part II, pp: 831-871. Page, A.L., R.H. Miller and D.R. Keeney (eds.). American Society of Agronomy, Madison, Wisconsin, USA

Khan, A., M.T. Jan, A. Jan, Z. Shah and S. Ali, 2008a. "Tillage and nitrogen management in a wheat-maize farming system." In" Global Issues Paddock Action. Unkovich, M. (ed.). Proceedings of the 14th Australian Agronomy Conference. Australian Society of Agronomy, Adelaide South Australia

Khan, A., M.T. Jan, K.B. Marwat, M. Arif and A. Jan, 2008b. Phenology and crop stand of wheat as affected by nitrogen sources and tillage systems. Pak. J. Bot., 40: 1103-1112

Kravchenko, A.G. and K.D. Thelen, 2007. Effect of winter wheat crop residue on no-till corn growth and development. Agron. J., 99: $549-555$
López-Bellido, R.J., L. López-Bellido, F.J. López-Bellido and J.E. Castillo, 2003. Faba bean response to tillage and soil residual nitrogen in a continuous rotation with wheat (1.) under rainfed mediterranean conditions. Agron. J., 95: 1253-1261

Malhi, S.S., R. Lemke, Z.H. Wang and B.S. Chhabra, 2006. Tillage, nitrogen and crop residue effects on crop yield, nutrient uptake, soil quality and greenhouse gas emissions. Soil Till. Res., 90: 171-183

Nakamoto, T., J. Yamagishi and F. Miura, 2006. Effect of reduced tillage on weeds and soil organisms in winter wheat and summer maize cropping on Humic Andosols in Central Japan. Soil Till. Res., 85: 94-106

Ortega, R.A., G.A. Peterson and D.G. Westfall, 2002. Residue accumulation and changes in soil organic matter as affected by cropping intensity in no-till dryland agroecosystems. Agron. J., 94: 944-954

Ouédraogo, E., A. Mando and L. Stroosnijder, 2006. Effects of tillage, organic resources and nitrogen fertiliser on soil carbon dynamics and crop nitrogen uptake in semi-arid West Africa. Soil Till. Res., 91: $57-67$

Papini, R., G. Valboa, C. Piovanelli and G. Brandi, 2007. Nitrogen and phosphorous in a loam soil of central Italy as affected by 6 years of different tillage systems. Soil Till. Res., 92: 175-180

Patil, S.L. and M.N. Sheelavantar, 2006. Soil water conservation and yield of winter sorghum (Sorghum bicolor L. Moench) as influenced by tillage, organic materials and nitrogen fertilizer in semi-arid tropical India. Soil Till. Res., 89: 246-257

Rasmussen, K.J., 1999. Impact of ploughless soil tillage on yield and soil quality: A Scandinavian review. Soil Till. Res., 53: 3-14

Rasool, R., S.S. Kukal and G.S. Hira, 2007. Soil physical fertility and crop performance as affected by long term application of FYM and inorganic fertilizers in rice-wheat system. Soil Till. Res., 96: $64-72$

Sainju, U.M., W.F. Whitehead, B.P. Singh and S. Wang, 2006. Tillage, cover crops, and nitrogen fertilization effects on soil nitrogen and cotton and sorghum yields. Eur. J. Agron., 25: 372-382

Semenov, M.A., P.D. Jamieson and P. Martre, 2007. Deconvoluting nitrogen use efficiency in wheat: A simulation study. Eur. J. Agron., 26: 283-294

Soon, Y.K., G.W. Clayton and W.A. Rice, 2001. Tillage and previous crop effects on dynamics of nitrogen in a wheat-soil system. Agron. J., 93: 842-849

Thomas, G.A., G.W. Titmarsh, D.M. Freebairn and B.J. Radford, 2007. Notillage and conservation farming practices in grain growing areas of Queensland - a review of 40 years of development. Aust. J. Exp. Agric., 47: 887-898

Walters, D.T., M.S. Aulakh and J.W. Doran, 1992. Effects of soil aeration, legume residue and soil texture on transformations of macro- and micronutrients in soils. Soil Sci., 153: 100-107

Wang, W.J. and R.C. Dalal, 2006. Carbon inventory for a cereal cropping system under contrasting tillage, nitrogen fertilisation and stubble management practices. Soil Till. Res., 91: 68-74

Westerman, R.L., 1990. Soil Testing and Plant Analysis, $3^{\text {rd }}$ edition. American Soil Science Society, Madison, Wisconsin, USA

Wiatrak, P.J., D.L. Wright and J.J. Marois, 2006. The impact of tillage and residual nitrogen on wheat. Soil Till. Res., 91: 150-156

Wong, J.W.C., K.K. Ma, K.M. Fang and C. Cheung, 1999. Utilization of a manure compost for organic farming in Hong Kong. Biores. Tech. 67: $43-46$

Yadvinder-Singh, Bijay-Singh, J.K. Ladha, C.S. Khind, T.S. Khera and C.S. Bueno, 2004. Effects of residue decomposition on productivity and soil fertility in rice-wheat rotation. Soil Sci.. Soc. Amer. J., 68: 854-864

Yinbo, G., M.B. Peoples and B. Rerkasem, 1997. The effect of N fertilizer strategy on N2 fixation, growth and yield of vegetable soybean. Field Crops Res., 51: 221-229

(Received 21 February 2013; Accepted 11 September 2013) 